\author{
ARTUR ŁAWNICZAK \\ ORCID: 0000-0002-0611-7176 \\ Uniwersytet Wrocławski \\ Katedra Prawa Konstytucyjnego
}

\title{
KILKA UWAG NA TEMAT POWSTAWANIA I CHARAKTERU KONSTYTUCYJNYCH USTROJÓW PRAWNOPOLITYCZNYCH BYŁEGO TRZECIEGO ŚWIATA
}

\begin{abstract}
Abstrakt: Sformalizowany konstytucjonalizm ogarnął prawie cały glob, a zatem także państwa byłego Trzeciego Świata. Weszły one na drogę wymoszczoną przez twórców Ustawy Zasadniczej USA. Najpierw wkroczyły na nią latynoamerykańskie państwowości oraz będąca ,afrykańską kopią" Stanów Zjednoczonych Liberia. Następnie do tego grona dołączyły zdekolonizowane państwa Czarnego Lądu, Azja wraz z Chinami i Indiami oraz Oceania. Szczególny obszar „biednego Południa" konstytuują islamskie kraje, w których wciąż jeszcze najważniejsze prawo dyktuje Koran. W większości wypadków mamy do czynienia z ubraną w konstytucyjną szatę monokracją, będącą pierwotnym czy też naturalnym ustrojem tworzonej przez ludzi wspólnoty politycznej, i trudno oczekiwać, żeby ten stan rzeczy uległ zmianie, skoro konstytucjonalizm oraz liberalne ludowładztwo przestały się rozwijać.
\end{abstract}

Słowa kluczowe: konstytucja, konstytucjonalizm, ustrój polityczny, kraje Trzeciego Świata

Obrady polskiego Okrągłego Stołu, a następnie upadek berlińskiego Muru, będące zapowiedzią końca Związku Radzieckiego, oznaczały poważne zmiany na globalnej scenie geopolitycznej, jako że w sporym stopniu doszło do implozji Drugiego Świata, rozumianego jako skupiony wokół ZSRR tak zwany Obóz Pokoju i Socjalizmu. Dotychczasowy konkurencyjny wobec północnoatlantyckiego modelu radziecki wzorzec demosocjalizmu przestał być wcielany w życie w moskiewskiej centrali, co — czemu trudno się dziwić — spowodowało odejście od niego we wschodnioeuropejskich państwach, które po II wojnie światowej zostały zdominowane przez ZSRR. Przyjęły one demoliberalny paradygmat, obowiązujący na zwycięskim Zachodzie i ogłoszony przez Fukuyamę jako jedynie słuszny, ergo bezalternatywny w ogólnoziemskiej skali.

Wkrótce okazało się jednak, że tak nie jest, ponieważ świat jest zbyt skomplikowany, aby bez specjalnych utrudnień zaprowadzić we wszystkich krajach 
konstytucyjnie usankcjonowany demoliberalny porządek. Jego krzewienie spotyka się ze szczególnymi trudnościami na rozległych obszarach niegdysiejszego Trzeciego Świata, wyróżniającego się po upadku kolonialnych imperiów tym, że popularność zyskiwało w nim hasło niezaangażowania w „dwublokowy klincz”, co czasem szło w parze z mniej lub bardziej udaną próbą podążania własną drogą społeczno-politycznego rozwoju, która to swoistość znajdowała swój prawnopolityczny wyraz również $\mathrm{w}$ ich zinstytucjonalizowanym konstytucjonalizmie oraz coraz bardziej przesycanym wraz ze zbliżaniem się do naszych czasów demokratyzmem republikanizmie.

Zjawiska te zasadniczo zostały importowane z „francusko-północnoamerykańskiej kolebki”, co oznacza, że nie są one oryginalnym wytworem niezachodnich ludów, które przyjęły je wszakże wraz z pozostałym „,dobrodziejstwem postkolonialnego inwentarza" jako symbol progresywistycznych aspiracji. Konstytucja jest zatem traktowana jako niezbędny element współczesnej państwowości, wymagającej podobno „spisanej instrukcji obsługi”, podniesionej do rangi Ius Supremum, niezbędnego w tej postaci dla każdej monarchii czy też republiki. Powstaje wszakże pytanie, czy konstytucjonalizacja w Ameryce Łacińskiej, Azji, Afryce czy Oceanii jest zbliżona swoim charakterem do rozkrzewiania się tego zjawiska na obrzeżach Północnego Atlantyku?

Trudno się spodziewać, aby właśnie tak było z powodu nieodmiennie występujących na obszarze ziemskiego globu poważnych cywilizacyjnych różnic. Wszak cieszące się wciąż jeszcze sporym poważaniem tradycyjne metody zbiorowego życia znacznie różnią się od siebie w poszczególnych częściach universum, co sprawia, że wszelkiego rodzaju zapożyczenia nolens volens zmieniają swoją pierwotną tożsamość również wówczas, gdy ich forma nie odbiega specjalnie od oryginału. Wypada zatem postawić hipotezę że, generalnie rzecz biorąc, często połączony z importowaniem ustrojowych instytucji konstytucjonalizm „biednego Południa" bynajmniej nie stanowi wiernej, przesiąkniętej aksjosferą oryginału, kopii pierwowzoru. Jest raczej dość mechanicznym przeniesieniem jednego z „wynalazków niespokojnej białej rasy” do odległych części świata, gdzie tamtejsze elity uznały, że wypada, po cielesnym odzianiu się na europejski wzór, przystroić własne ustroje polityczne $\mathrm{w}$ importowane z niegdysiejszych kolonialnych metropolii kostiumy.

Najpierw eksperyment ten znalazł zastosowanie na zachodniej półkuli, gdzie w 1801 roku weszła w życie, przynajmniej teoretycznie, Konstytucja Saint-Domingue (Haiti), sprzymierzonej z Francją, drugiej w Nowym Świecie republiki².

${ }^{1}$ Gdyby podążać za dzisiejszą ideową modą, zapewne wypadałoby użyć stwierdzenia „bogate inaczej Południe”, co pozwoliłoby uniknąć „nienawistnej stygmatyzacji”. Skutek byłby taki, że doszłoby do powiększenia semantycznej zapaści, zacierającej nieuniknione wszak dystynkcje, bez których przecież „nie można się pięknie różnić”.

2 O pierwszym okresie jej dziejów zob. T. Łepkowski, Haiti: początki państwa i narodu, Warszawa 1964, passim. 
Po upływie wielu dekad od tamtej pory trudno z całym przekonaniem stwierdzić, że wejście na konstytucyjny szlak pierwszego uformowanego w nowożytności murzyńskiego (politpoprawnie będzie rzecz jasna „afroamerykańskiego”) państwa przyniosło mu, niezależnie od późniejszych prawnopolitycznych przekształceń, prowadzących ostatecznie po monarchicznych interwałach do przywrócenia prezydenckiej republiki, jakieś szczególne korzyści. W każdym razie rzeczony precedens zapowiadał intensywną konstytucjonalizację prawnopolitycznej rzeczywistości uwalnianych z transoceanicznej zależności latynoskich państwowości. Powielano w nich północnoamerykański schemat, uzupełniany w wypadku haitańskiej, meksykańskiej czy też brazylijskiej monarchii o inspiracje płynące z Karty Ludwika XVIII, będącej wszak etalonem dziewiętnastowiecznych konstytucyjnych koronowanych monokracji ${ }^{3}$. Trudno wszak oprzeć się wrażeniu, że pochodząca z innej, nasączonej starotestamentowym kultem prawa, cywilizacji wizja podporządkowania całokształtu rzeczywistości wyniesionemu na świeckie ołtarze „najwyższemu dokumentowi” nie do końca sprawdza się w żywiołowych, nieskłonnych do rygoryzmu społeczeństwach, źle się czujących w przesadnie ciasnych w powszechnym odczuciu jurydycznych gorsetach. Zdaje się, że właśnie z tego względu importowany z Waszyngtonu kult Najwyższego Spisanego Prawa, mający być „skuteczną odtrutką na absolutystyczne iberyjskie złogi”, wpłynął w niewielkim stopniu na tożsamość romanoamerykańskich ludów, w przeciwieństwie do „zręcznie posługującego się orężem konstytucjonalizmu i zbrojnego interwencjonizmu Wuja Sama". W sporej mierze wynika to z tego, że Stany Zjednoczone są ekstrapolacją rodzinnej przeprawy przez Wielką Wodę pasażerów Mayflowera, których potomkowie w genetyczno-ideowym wymiarze do dzisiaj władają w stworzonych in cruda radice USA, podczas gdy na południe od Rio Bravo niejednokrotnie mamy do czynienia z indoamerykańskimi państwowościami, zanurzonymi zarówno w kolonialno-europejskiej, jak i w indygeńskiej przeszłości.

W rezultacie ich obywatele nie tworzą zwartej całości, gdyż wciąż jeszcze są traktowani i sami siebie postrzegają jako potomków bądź konkwistadorów, bądź

${ }^{3}$ Nie wzorowano się zatem na przedrewolucyjnym modelu absolutnej, pozbawionej zapisanej ustawy zasadniczej monarchii, choć konserwatyści „opowiadali się za silną władzą centralną o szerokich kompetencjach, najlepiej skupioną w ręku monarchy [...]. Liberałowie natomiast pragnęli naśladować wzorce brytyjskie, francuskie i północnoamerykańskie. W teorii pragnęli władzy zdecentralizowanej, z luźną konfederacją stanów lub prowincji” — M.C. Eakin, Historia Ameryki Łacińskiej. Zderzenie kultur, Kraków 2009, s. 201. Rzeczone angielskie inspiracje były w dużej mierze przesączone przez waszyngtoński lub paryski filtr, jednakże trudno zaprzeczyć roli, jaką odegrał angielski parlamentaryzm oraz myśl prawnopolityczna Albionu w kształtowaniu ustrojowego oblicza nowożytnego globu. Trudno też nie zauważyć, że zarówno w Nowym Świecie, jak i w zdecydowanej większości położonych gdzie indziej państwowości uznano, że zainstalowanie wzorowanej mniej lub bardziej na angielskiej legislatywy nie powinno skutkować przyznaniem jej nadmiernych kompetencji, w związku z czym pojawił się zainicjowany przez USA znaczący prezydencjalizm, w rozlicznych wypadkach osiągający większe natężenie niż w Stanach Zjednoczonych. 
podbitych. W takim stanie rzeczy trudno spodziewać się, aby w nieanglosaskiej Ameryce rozkwitały ,prokonstytucyjnie nastawione społeczeństwa obywatelskie", które byłyby udanymi kopiami USA. Znamienne jest to, że nawet niemalże pozbawiona tubylczej ludności, stworzona przede wszystkim przez wychodźców z Hiszpanii i Włoch Argentyna, zdająca się jeszcze w pierwszych dekadach ubiegłego stulecia udanym eksperymentem ustrojowym, poszła następnie typową dla Latynoameryki anarchistyczno-populistyczno-dyktatorską drogą, stając się ,skłębionym rojowiskiem peronistów oraz ich wrogów", a w efekcie wygodnym celem krytyki wyznawców prawoczłowieczej ideologii.

Caeteris paribus podobnie było w Chile, które do narastającego podczas prezydentury Allende nieładu, skutkującego puczem Pinocheta, cieszyło się zarówno na Zachodzie, jak i Wschodzie całkiem solidną reputacją. Mniej więcej to samo możemy powiedzieć o — podobnie jak dwie dopiero co wymienione republiki zasadniczo zamieszkałym przez białych Urugwaju, nazywanym po II wojnie światowej Szwajcarią Południowej Ameryki, póki nie doszło tam do ekspansji miejskiej partyzantki, kontestującej zbrojnie militarne reżimy. Za przykład odwrotnej ewolucji może zaś służyć Kostaryka, gdzie od połowy XX wieku, po likwidacji sił zbrojnych, skończyły się wojny domowe i — przynajmniej póki co — możemy mówić o — trwającej już dobrych kilka dekad — konstytucyjnie ugruntowanej liberalnej demokracji parlamentarnej. Jednak ze znacznie mniejszym przekonaniem można tak scharakteryzować formalnie podobne w swojej federalnej strukturze do USA Brazylię i Meksyk, jak też Wenezuelę i Kolumbię, Boliwię i Salwador etc. Generalnie rzecz ujmując, wypada uznać, że przeszczepienie republikalnego konstytucjonalizmu znad Potomaku do romanoamerykańskich ostępów nie zakończyło się oszałamiającym sukcesem, choć rzecz jasna nie dowiemy się, co by się stało, gdyby do tego nie doszło, z czego wynika, że być może konstytucjonalizacja latynoamerykańskiej rzeczywistości jest mniejszym złem.

W ustrojowoprawnym wymiarze w XIX wieku największym wyzwaniem dla Wuja Sama na zachodniej półkuli były istniejące w Haiti, Meksyku i Brazylii monarchie ${ }^{4}$, podążające zatem odrębną drogą, wzorowaną, szczególnie w wypadku położonych na kontynencie państw, na francuskiej monarchii konstytucyjnej. Wydaje się wszakże, że po ostatecznej, przynajmniej na razie, republikanizacji Ameryki Łacińskiej za największe prawnopolityczne wyzwanie wypada uznać casus Kuby. Wszak to właśnie tam, na będącej największą z karaibskich wysp

${ }^{4}$ W każdym z tych trzech państw w XIX stuleciu proklamowano najbardziej prestiżową postać monarchii, jaką jest cesarstwo, przy czym w Meksyku i Haiti podczas ustanawiania, względnie likwidacji, takiej odmiany państwowości nie obeszło się bez rozlewu krwi, natomiast w Brazylii ,nieco pompatyczna forma ustrojowa Cesarstwa kontrastowała z brakiem choćby jednej poważniejszej bitwy" - M. Kula, Historia Brazylii, Wrocław-Warszawa-Kraków 1987, s. 70. Nie doszło do niej ani przy powstawaniu, ani przy likwidacji cesarstwa, co można interpretować w ten sposób, że dla Brazylijczyków, podobnie jak na przykład dla Polaków, kwestia formy państwa nie ma większego znaczenia. 
Perle Antyli, po 1959 roku ustanowiono prawnopolityczny porządek, odwołujący się zasadniczo do tych samych wartości, jakie przyświecały kreatorom północnoatlantyckiego, ergo francusko-anglosaskiego, konstytucyjnego porządku, który jednakże został na początku XX wieku przeformatowany w wybitnie radykalną postać, wzorcowo ucieleśnioną w ustrojowym modelu Kraju Rad. Odznaczał się on wyciągnięciem daleko idących konsekwencji z fenomenu wymierzonych w Stary Porządek - zapowiadających koniec feudalizmu, a następnie socjalistyczne zagrożenie dla jego kapitalistycznego grabarza - rewolucji, jakie wstrząsnęły Zachodem między 1572 a 1848 rokiem. Brodaci niemieccy filozofowie w postaciach Karola Marksa i Fryderyka Engelsa w okolicach drugiej z wymienionych dat wydali Manifest komunistyczny, będący socjalistycznym odpowiednikiem egzaltowanego Zdrowego rozsądku Tomasza Paine'a czy też brzemiennej w skutki broszury Czym jest stan trzeci? Emmanuela Sieyèsa. W drugiej połowie XX stulecia oparty na marskistowsko-leninowskim przesłaniu model państwowości jawił się jako atrakcyjny, bo alternatywny, wobec istniejących na zachód od żelaznej kurtyny porządków.

Ten właśnie wzgląd zadecydował o tym, że na przekór jankeskim roszczeniom w Hawanie po upadku Batisty zainstalowano reżim socjalistyczny. W konstytucyjno-ustrojowym wymiarze oznaczało to stworzenie pod bokiem Stanów Zjednoczonych schizmatyckiej czy też może protestanckiej względem waszyngtońsko-jeffersonowskiego modelu nomokratyczno-pluralistycznej państwowości republiki, opartej jak najbardziej, podobnie jak USA, na konstytucyjności i republikańskości, odróżniającej się jednak daleko posuniętym nieliberalnym ludowładztwem ${ }^{5}$, bazującym na russoistycznym założeniu konieczności urzeczywistniania per fas et nefas zmitologizowanej Woli Powszechnej. W przeniesionym na Wyspę Wolności radzieckim paradygmacie zakładano, że owa Volonté Générale jest najlepiej znana przez bezbłędnie rozumiejących prawidłowości dziejowego

${ }^{5}$ Żeby uświadomić sobie znaczenie kubańskiego przypadku, warto przypomnieć, że „począwszy od połowy XVIII wieku połączenie liberalizmu politycznego z gospodarką kapitalistyczną doprowadziło do powstania w Ameryce Północnej i Europie demokratycznych ustrojów kapitalistycznych, które opanowały światową gospodarkę i politykę pod przewodem Wielkiej Brytanii w XIX i Stanów Zjednoczonych w XX wieku" - M.C. Eakin, op. cit., s. 299. Wyzwanie rzucone owej anglosaskiej hegemonii przez Związek Radziecki uległo nasileniu po 1945 roku, gdy stał się on światowym mocarstwem, obejmującym swoimi wpływami sporą część Europy i Azji. Zastąpił zatem w dużej mierze na obszarze Starego Świata coraz bardziej słabnącego „chorego człowieka znad Tamizy", pozostającego jednakże wraz z innymi eurookcydentalnymi krajami w strategicznym sojuszu z Wujem Samem, który po powtórnym pokonaniu Niemiec śmiało porzucił niegdysiejszy izolacjonizm, nieprzeszkadzający bynajmniej również wcześniej w podporządkowywaniu swym wpływom Romanoameryki w myśl zawołania America for Americans, skutkującego konsekwentnym niwelowaniem wpływów innych potencji po zachodniej stronie Atlantyku. $Z$ tego właśnie względu ewidentnie kwestionujące doktrynę Monroe rozciągnięcie radzieckiej strefy wpływów na Kubę, skutkujące rozmieszczeniem na tejże sowieckich rakiet dalekiego zasięgu, było dla jankesów szokiem, przypominającym nieco pojawienie się niemieckich czołgów na przedpolach Moskwy w 1941 roku. 
rozwoju i zawiłości dialektyczno-historycznego materializmu członków kompartii, predestynowanych do tego, aby wskazywać mniej uświadomionym współobywatelom kierunek rozwoju. Takie przeświadczenie sprawiło, że po tryumfie rewolucji na Kubie zrezygnowano z organizowania wyborów, uznając, że typowa dla rewolucyjności wiecowość jest znacznie lepszym sposobem legitymizacji władania Fidela Castro et consortes.

Oznaczało to, że parlamentaryzm został zasadniczo zepchnięty na margines społeczno-politycznej rzeczywistości w imię powrotu do charakterystycznych dla trybalistycznych społeczności praktyk odwoływania się do aklamacyjnego poparcia gromadzonych na rozległych przestrzeniach ludzkich mas, z założenia udzielających entuzjastycznego poparcia charyzmatycznemu przywódcy, nieprzejmującemu się specjalnie konstytucyjnymi niuansami. O nieprzywiązywaniu szczególnej wagi do spisanego Najwyższego Prawa świadczy to, że dopiero w 1976 roku, a zatem siedemnaście lat po zwycięstwie Rewolucji, uchwalono nowe Ius Supremum, będące kubańską emanacją słynnej stalinowskiej Konstytucji ZSRR, stanowiącej w globalnej skali najbardziej znane przekształcenie stworzonego w 1787 roku przez północnoamerykańskich Ojców Założycieli jurydycznego etalonu. W 2019 roku Kuba doczekała się nowej Ustawy Zasadniczej, w której przywrócono nieobecną $\mathrm{w}$ klasycznym radzieckim wzorcu prezydenturę, uznano własność prywatną oraz zrezygnowano z zapowiedzi komunizmu, choć w dalszym ciągu deklaruje się socjalistyczny charakter pozbawionej oficjalnej opozycji republiki, idącej aktualnie chińskim szlakiem ${ }^{6}$.

Doszło zatem w Ameryce, czy też Amerykach, do rywalizacji między wzorcami liberalnym a socjalistycznym skonstytucjonalizowanej państwowości. W propagowanej przez Waszyngton wersji powinna ona być przepełniona wolnorynkowym paradygmatem, będącym w naturalny według Anglosasów sposób kompatybilnym ze swobodną rywalizacją na politycznej arenie, prowadzącą do zdobywania od czasu do czasu władzy przez dotychczasową opozycję, mającą — podobnie jak konkurencja w sferze gospodarczej — „święte prawo do istnienia”. Aby zapobiec zbytniej koncentracji politycznej siły, należy wcielać w życie monteskiuszowski dogmat, nakazujący instalację trójpodziału władzy, co ma być skuteczną zaporą przeciw wszelkiej despocji, względnie tyranii, absolutyzmowi, samodzierżawiu, ergo rozmaitym postaciom jedynowładztwa, kłócącego się z dość konsekwentnie lansowaną nad Potomakiem zasadą incompatibilitas. Jak się nietrudno domyślić, radziecki model, będący radykalną wariacją czy może raczej kontynuacją jakobińskiej, ergo skrajnej, fazy francuskiego wielkiego rewolucyjnego wzmożenia z przełomu XVIII i XIX wieku, pomimo hołdowania konstytucjonalizmowi i republikanizmowi w pozostałych, być może drugorzęd-

${ }^{6}$ Kuba proklamowała nowa konstytucję. Castro: przygotujcie się na braki w zaopatrzeniu, https://tvn24.pl/swiat/kuba-nowa-konstytucja-proklamowana-przez-zgromadzenie-narodowe-ra926432-2310532 (dostęp: 15.02.2020). 
nych w oświeceniowej, antymonarchicznej i głoszącej chwałę spisanej Umowy Społecznej prawnopolitycznych kwestiach, tym niemniej w XX stuleciu traktowanych jako kreujące fundamentalne różnice między Wolnym Światem a Obozem Pokoju i Socjalizmu aspektach, odróżnia się od jankeskiego. Został bowiem oparty na skolektywizowanej gospodarce, nad którą została nadbudowana totalitarna państwowość, owładnięta przez pozbawioną jakiejkolwiek konkurencji komunistyczną partię, której wyznający marksistowsko-leninowską wizję rzeczywistości przywódcy konsekwentnie negowali i negują potrzebę, szczególnie konfrontacyjnego, pluralizmu, niemożliwego do pogodzenia z wszechogarniającą jednością moralno-polityczną, mającą przenikać wszelkie komórki unifikowanego przez bazujący na niekwestionowalnej zasadzie jedności władzy państwowej zinstytucjonalizowanego aparatu ucisku. Przyzwolenie na ekonomiczną inicjatywę prywatną w ograniczonym zakresie jest doktrynalnie traktowane jako taktyczna zagrywka w celu uzyskania na wzór leninowskiego NEP-u niezbędnej передьики.

Kuba była zatem, i w sporym stopniu jeszcze jest, w ideologiczno-prawnopolitycznym i nie tylko tym wymiarze ,jątrzącym wyzwaniem pod samym bokiem Imperialistycznego Giganta”, względnie ,prowokacyjnie zbudowanym przed progiem wrażej Ameryki pomniejszonym Krajem Rad", rzucającym wyzwanie zdominowanemu przez USA Nowemu Światu. Gdybyśmy chcieli poszukać odwrotnego przykładu na wschodniej półkuli, w pierwszej kolejności wypadałoby wymienić Liberię, będącą — przynajmniej w założeniu — wzorcowym przykładem przybranego w państwowość przeniesienia amerykańskiego marzenia przez Atlantyk. Wszak afrykańskie państwo, którego stolica symbolicznie została nazwana na cześć głosiciela doktryny Monroe Monrovią, zostało stworzone po to, aby zademonstrować Staremu Światu zwycięstwo wolnościowego ideału w zniewolonej przez Europejczyków po wyparciu ich z zaoceanicznych posiadłości Afryce.

Trudno nie dostrzec $\mathrm{w}$ powstaniu tej państwowości realizacji typowego dla liberalnego kapitalizmu przekonania o niezwykłej skuteczności prywatnych przedsięwzięć, gdyż afrykańska republika powstała wskutek inicjatywy północnoamerykańskich abolicjonistów, którzy postanowili ulżyć doli niewolników z Dixielandu poprzez ich wykupienie i odesłanie na kontynent, z którego przybyli ich przodkowie ${ }^{7}$. Zakładano, że zaznajomieni przez swoich dobroczyńców z oświeceniową wizją racjonalnej wspólnoty politycznej wyzwoleńcy stworzą na Czarnym Lądzie przykładną państwowość, podziwianą następnie jako pierwszy przykład transatlantyckiego rozprzestrzeniania się amerykańskiego wzorca. Nie

7 „Liberia zawdzięcza swe powstanie postanowieniu towarzystw kolonizacyjnych w Waszyngtonie, które, nabywszy za pieniądze część wybrzeża, osiedliły na niem 30 rodzin negrów ze Stanów Zjednoczonych. Następnie kolonja powiększała się przez przyjazd nowych kolonistów z Ameryki i łączenie się plemion sąsiednich, tak że w 1847 r. została przez mocarstwa europejskie uznana za rzeczpospolitę niepodległą" — Liberja, [w:] S. Orgelbrand, Encyklopedja powszechna z ilustracjami i mapami, t. 9, Warszawa 1901, s. 287. 
da się przecież ukryć, że liberyjski ustrój polityczny został stworzony na „obraz i podobieństwo" tego, co wykreowano w USA. Trudno dojść do innego wniosku, skoro Prezydent Republiki Liberii jest wybierany wraz z wiceprezydentem na sześcioletnią kadencję w powszechnych wyborach. W ten sam sposób przeprowadzana jest elekcja mających sześcioletni mandat członków Izby Reprezentantów, jak też drugiej części legislatywy w postaci Senatu, gdzie kadencję wydłużono do dziewięciu lat ${ }^{8}$. Jak zatem widzimy, w szczegółach liberyjski reżim polityczny różni się od ,jedynie słusznego wzorca”, tym niemniej mamy tu do czynienia z jego kopiowaniem ${ }^{9}$, jak najbardziej porównywalnym z powielaniem w tym samym, XIX stuleciu modelu francuskiej monarchii konstytucyjnej w Europie i Ameryce czy też przenoszeniem w następnym wieku radzieckiego schematu prawnopolitycznego do zaprzyjaźnionych z Krajem Rad republik.

Takie przeszczepy narażone są na wiele zagrożeń wynikających z cywilizacyjnych odmienności, o czym możemy się ewidentnie przekonać na przykładzie Liberii. Doszło w niej bowiem do powtórzenia kolonizacyjnego schematu, przy czym w roli konkwistadorów wystąpili przywiezieni przez mających jak najlepsze intencje naiwnych abolicjonistów byli niewolnicy, którzy bynajmniej nie zintegrowali się z miejscową ludnością, nierozumiejącą za bardzo sensu dokonywanego eksperymentu. Doszło więc do przymuszenia żyjących wciąż w trybalistycznej rzeczywistości tubylców do formalnego współuczestniczenia w kierowanej przez przybyszów wspólnocie politycznej. Została ona ozdobiona szczytnymi hasłami, brzmiącymi jednak obco dla rdzennych Afrykanów, którym przypadła do odegrania rola dostarczania oddolnej legitymizacji rządzącej warstwie, przypominającej w dużej mierze zamkniętą dla ludzi spoza niej kastę, ergo mamy tu do czynienia z klasycznym rzeczywistym pozbawieniem możliwości współrządzenia zdecydowanej większości obywateli, którzy ostatecznie w 1980 roku odsunęli od władania „pyszną kastę Afroamerykanów”.

Poza będącą najbardziej jaskrawym exemplum przeniesienia dalekich wzorców na Czarny Ląd Liberią odnajdziemy na nim, w jego subsaharyjskiej części, przekształcone na miejscowy użytek euroamerykańskie modele, przyjmujące prezydencjalistyczną postać, zazwyczaj mniej wyrazistą niż w wypadku zachodnioafrykańskiej „Republiki Wolnych Murzynów”, tym niemniej potwierdzającą prawidłowość odkształcenia powstałego w innym miejscu i odmiennych okolicznościach schematu wskutek przeniesienia go gdzie indziej, skutkującego niezbędnością dostosowania do lokalnych warunków. W rezultacie doszło do powstania charakteryzujących się wybitnie wzmocnioną pozycją głowy państwa reżimów,

${ }^{8}$ E.G. Smirnow, Obszczije swiedienija, nasielienije, chozjastwo, [w:] Liberija, „Bol'szaja Rossijskaja Encikłopiedija", https://bigenc.ru/geography/text/2649384 (dostęp: 8.02.2020).

${ }^{9}$ Oprócz wskazanych już jego przejawów nie zaszkodzi przytoczyć jeszcze takie jak budowa w Monrovii Kapitolu lub posługiwanie się ewidentnie przypominającą amerykańską flagą państwową — Libierija: pieczial'naja istorija ,,Swobodnoj strany”, https://topwar.ru/54963-liberiya-pechalnaya-istoriya-svobodnoy-strany.html (dostęp: 8.02.2020). 
w których zazwyczaj konstytucyjno-republikańska fasada przesłania absolutystyczną czy też autorytarną praktykę ustrojową.

Na tym tle przynajmniej formalną oryginalnością wyróżniają się dwa południowoafrykańskie królestwa, a mianowicie Suazi (Ngwane) i Lesotho, będące w dużej mierze przetrwalnikowymi formami pradawnych plemiennych monarchii, de facto istniejących wciąż wewnątrz postkolonialnych państwowości, lecz w przeciwieństwie do omówionych monokracji niebędących uznawanymi w prawie narodów podmiotami. Lesotho i Suazi przetrwały natomiast okres cudzoziemskiej inwazji, skutkującej formalnym przyjęciem w nich konstytucjonalizmu ${ }^{10}$ i parlamentaryzmu, traktowanych jako „nowomodne dodatki” do królewskości, wciąż decydującej o państwowoprawnej tożsamości owych państwowości, będących rzecz jasna toutes proportions gardées, „odległymi kuzynami” takich europejskich minimonarchii jak Andora, Monako czy Liechtenstein. Wszystkim im udało się przetrwać „nieznośny napór nowoczesności”, w związku z czym możemy uznać południowoafrykańskie monarchie za emanacje tradycyjnego jedynowładztwa, dzięki czemu łatwiej jest spełnić przesłanie „by czas nie zatarł i niepamięć" wizję drzewiejszego ustrojowego paradygmatu.

Idąc dalej, należy wskazać, że gdy obejmiemy poznawczym spojrzeniem pozostałą część niegdysiejszego Trzeciego Świata, trudno będzie przeoczyć nazywane często największą demokracją świata Indie, które to określenie, oprócz tego, że zapoznaje niemożliwość funkcjonowania ludowładztwa w większych od antycznych miast-państw wspólnotach politycznych, dodatkowo jeszcze odmawia demokratycznego rysu Chinom. W indyjskim przypadku mamy bowiem do czynienia z typowym dla narracji бывщего Pierwszego Świata automatycznym łączeniem demokratyczności ze zinstytucjonalizowaną rywalizacją o władzę, podczas gdy związek ten bynajmniej nie jest oczywisty. W każdym razie Bharat Ganaradźja jest w globalnej skali najpokaźniejszą wariacją porewolucyjnego brytyjskiego modelu państwowości, obdarzoną co prawda po uwolnieniu się spod albiońskiego panowania Ustawą Zasadniczą, lecz nieuchylającą się od aplikowania parlamentarno-gabinetowego systemu rządów, skutkującego usymbolicznieniem politycznej roli republikańskiej w indyjskim wypadku głowy państwa, zdominowanej, podobnie jak w Zjednoczonym Królestwie, przez mogącego zazwyczaj liczyć na absolutną większość w parlamentarnych głosowaniach premiera ${ }^{11}$. Ergo wypada uznać indyjski casus za niezwykle ważki, ze względu na znaczenie tej państwowości, wyjątek od przemożnego, zdaje się, w byłym Trzecim Świecie prezydencjalistycznego trendu.

${ }^{10}$ Zob. Królestwo Lesotho. Konstytucja z dnia 2 kwietnia 1993 r., http://biblioteka.sejm.gov. pl/konstytucje-swiata-lesotho/ (dostęp: 15.02.2020); Królestwo Suazi. Konstytucja z dnia 26 lipca 2005 r., http://biblioteka.sejm.gov.pl/konstytucje-swiata-suazi/ (dostęp: 15.02.2020).

${ }^{11}$ Tak czy owak na scenie politycznej wybija się zatem jednostka, ergo monokratyzacja jest trudna do uniknięcia. 
Przy odrobinie dobrej czy też właściwej woli odnajdziemy go w Chinach, gdzie co prawda doktrynalnie wciąż podkreśla się znaczenie francusko-radzieckiej rewolucyjnej koncepcji kolektywnego kierownictwa, tym niemniej ustrojowa pozycja wybieranego przez Ogólnochińskie Zgromadzenie Przedstawicieli Ludowych Przewodniczącego ChRL, będącego jednocześnie — przynajmniej aktualnie — gensekiem kierowniczej siły narodu w postaci KPCh, jest na tyle znacząca, że trudno nie dostrzec, nieuchronnej nota bene poza rzadkimi przypadkami w rodzaju Szwajcarii, monokratyzacji prawnopolitycznego reżimu, w wypadku Kraju Środka z pewnością ułatwionej wielowiekową tradycją cesarskiego jedynowładztwa ${ }^{12}$. Jej pokłosie odnajdziemy w zasadzie jedności władzy państwowej, umożliwiającej grupie bądź jednostce skupianie potężnej władzy ${ }^{13}$.

Aktualnie Pekin po wydostaniu się z odmętów Rewolucji Kulturalnej jest największym rywalem Waszyngtonu na globalnej arenie, w związku z czym funkcjonująca nad Żółtą Rzeką formuła ustrojowa przypuszczalnie będzie zyskiwać na atrakcyjności ${ }^{14} \mathrm{w}$ świadomości sceptycznie nastawionych względem demoliberalizmu rządzących elit w wielu państwach niegdysiejszego Trzeciego Świata, którego Chiny Ludowe są naturalnym przywódcą jako kraj, który doświadczył onegdaj przemocy ze strony europejskich potencji. Niewykluczone zatem, że połączenie społecznej gospodarki rynkowej z autorytarną ludową demokracją będzie znajdować coraz więcej zwolenników jako synteza modeli północnoamerykańskiego oraz radzieckiego, względnie kompromis między nimi, ,przejmujący to, co w nich najlepsze, oraz odrzucający ich skrajności”.

Ciekawe, jak odniosą się do tego wyzwania muzułmańskie państwowości, będące dla obserwatora z zewnątrz, pomimo występujących pomiędzy nimi różnic, tą częścią universum, w której wciąż traktuje się religię, w przeciwieństwie do coraz bardziej postchrześcijańskiej Europy, niezwykle poważnie, co sprawia, że wiara nadal jest tam w publicznej sferze wszechobecna, a Koran ma zdecydowanie większe znaczenie niż konstytucje. Nadrzędna władza Allacha w prawnopolitycznym wymiarze jest tam czymś oczywistym, co sprawia, że wyniesiona w Euroameryce na świeckie ołtarze suwerenność ludu czy narodu w muzułmańskich krajach jest czymś wtórnym, niemogącym podważać boskiej preponderancji.

${ }^{12}$ Znawca zagadnienia twierdzi, że „pomimo wszystkich przejawów nowoczesności dzisiejsze Chiny oraz Państwo Środka z przeszłości to jeden i ten sam kraj”, w związku z czym trzeba „Mao Ze Donga uznać za potężnego i upartego założyciela nowej dynastii rządzącej” — J. Fenby, Chiny. Narodziny i upadek wielkiej potęgi, Kraków 2009, s. 895.

${ }^{13}$ Zob. J. Rowiński, W. Jakubiec, System konstytucyjny Chińskiej Republiki Ludowej, Warszawa 2006, passim.

${ }^{14}$ Przekonany jest co do tego na przykład wrocławski badacz, uważający, że Pekin stanie się nową Mekką odrodzonego międzynarodowego ruchu robotniczego czy też komunistycznego; zob. Z. Wiktor, Chiny na drodze socjalistycznej modernizacji, Torun 2008, passim. 
Najważniejszym wyjątkiem od tej prawidłowości była postsułtańska, republikańska i zlaicyzowana Turcja ${ }^{15}$, skierowana przez Atatürka na okcydentalny, prezydencjalistycznie nacechowany szlak rozwoju, przy czym w roli strażnika kemalistowskiego dziedzictwa występowała armia, obalająca te głowy państwa, które zaczęły być podejrzewane o zbaczanie z jedynie słusznego szlaku bądź też niepanowanie nad sytuacją, co skutkowało zachwianiem modelu ${ }^{16}$. Wynika $z$ tego, że mamy tu do czynienia $\mathrm{z}$ militokracją, często spotykaną także $\mathrm{w}$ innych azjatyckich (vide Birma), afrykańskich (Nigeria) oraz latynoskich (Brazylia e tutti quanti) państwowościach. Zdaje się jednak, że Erdoğan zmierza w stronę islamizacji, odpowiadając w ten sposób na oczekiwania przeważającej części społeczeństwa, przywiązanego do nasyconej, co prawda dość powierzchowną, muzułmańskością sułtańsko-kalifackiej tradycji.

Jej znaczenie, akcentujące potrzebę kultywowania prawdziwej wiary, sprawia, że skanonizowane przez UE ujmowanie demokracji jako panowania większości z (rosnącym) poszanowaniem praw mniejszości jest traktowane w Dar al-Islam z dystansem, gdyż w mahometańskim ujęciu mniejszości mogą być co najwyżej tolerowane, nie mogą natomiast liczyć na to, że monitorowana przez rzeczników praw wszelakich większość będzie uprzejmie zastanawiać się nad sposobami wzmożenia minorytokracji. Ze względu na wszechobecną konfesyjność w świecie islamu podstawowe znaczenie mają mniejszości religijne, które czasem mogą liczyć na to, że w sprzyjających okolicznościach, jakie na przykład powstały w rządzonej silną ręką przez partię BAAS Syrii, uda się jednej z nich, w tym wypadku alawitom, zdominować liczebnie przeważających sunnitów. Podobnie było w Iraku podczas władania Saddama Husajna, gdy sunnicka mniejszość zdominowała szyicką większość. W obu przypadkach nacjonalistyczno-socjalistyczne eksperymenty ustrojowe zmierzały strategicznie do laicyzacji,

${ }^{15}$ Lansowanie świeckości miało jednak dość łagodną postać, bo choć „W r. 1937 ogłoszono oficjalnie »laickość« państwa, to [...] charakter muzułmański nie uległ [...] na zewnątrz zmianie. Religia została ograniczona w swej działalności do meczetów, których część zamieniono zresztą na muzea. Nakazano również wprowadzenie języka tureckiego do służb religijnych oraz przełożono Koran na język turecki” - J. Reychman, Historia Turcji, Wrocław-Warszawa-Kraków 1973, s. 308. Mamy tu do czynienia z powtórką tego, co dokonało się we Francji na początku XX wieku, przy czym w Turcji rzadziej niż w również laicyzującym się Związku Radzieckim dochodziło do radykalnych przejaskrawień, co można tłumaczyć tym, że dla turkojęzycznych ludów islamska lub inna religia zasadniczo jest mniej ważna niż w wypadku bardziej fideistycznych Arabów.

${ }^{16}$ Tak właśnie wojskowi postrzegali sytuację na przykład pod koniec lat siedemdziesiątych. W rezultacie doszło „do przejęcia przez wojsko 12 września 1980 roku władzy w państwie. Na czele zamachu stanął generał Kenan Evren, który zdelegalizował partie polityczne i internował liderów partyjnych" - T. Goduń et al., Turcja (Republika Turecka), [w:] T. Goduń et al., Leksykon systemów politycznych, Warszawa 1999, s. 263. Schemat ten był i jest powielany w wielu trzecioświatowych państwowościach, w których armia odgrywa rolę instytucji mającej sanować co jakiś czas system polityczny. 
w dużym stopniu według tureckiego wzoru, państwowości ${ }^{17}$, co jednakże nie jest łatwym przedsięwzięciem.

Przekonał się o tym również Reza Pahlawi, pragnący poprzez Białą Rewolucję przekształcić Persję w „wyrwane ze szponów ciemnych mułłów nowoczesne Cesarstwo". W rezultacie doszło do rewolucji ajatollahów, która ustanowiła teokratyczną republikę, gdzie najwięcej do powiedzenia mają tworzący przypominającą Kościół rzymsko-katolicki strukturę muzułmańscy duchowni. Zdominowana przez nich państwowość wzbudza asocjacje ze starotestamentową żydowską wspólnotą polityczną, w której potężny wpływ mieli sędziowie i prorocy, który to model był inspiracją dla tworzącego genewską teokratyczną gminę Kalwina. Nadlemański ustrojowy model został następnie przeniesiony do Nowej Anglii, rojącej się od opanowanych przez protestanckich uczonych w Piśmie miast, które tworzyły zalążki oświeceniowo zlaicyzowanej republikańskiej Ameryki. Dzisiaj przygląda się ona z niepokojem indoeuropejsko-mahometańskiej wariacji państwa świętych mężów.

Przekształcono w nim na miejscową modłę importowany zza oceanu prezydencjalizm, pełniący pomocniczą rolę wskutek hołdowania zasadzie Welayat-e Faqih, oznaczającej, że najważniejszą pozycję w państwie zajmuje szyicki duchowny lub teolog, będący religijno-politycznym najwyższym autorytetem. Obok niego funkcjonuje Rada Strażników Konstytucji, czuwająca nad tym, aby tworzone przez Islamskie Zgromadzenie Konsultatywne (Madżles) prawo było prawidłowe ${ }^{18}$. Mamy więc $w$ tym przypadku do czynienia $z$ instytucjonalnie rozwiniętą nomokracją, niezważającą bynajmniej na północnoatlantyckie standardy, traktowane w oficjalnych kręgach Iranu co najmniej z dużą podejrzliwością, względnie przetwarzane według własnego aksjologicznego paradygmatu. Perska minorytokracja wyraża się przede wszystkim w tym, że mniejszości religijne mają swoich wirylistów w ciele ustawodawczym, gdzie — zgodnie z tradycją — powinno stać puste krzesło, na którym zasiądzie „ukryty imam” (Mahdi), gdy nadejdzie czas jego powrotu ${ }^{19}$, równoznacznego z rozprzestrzenieniem (na złość Amerykanom i innym niewiernym) irańskiego modelu ustrojowego na cały Orbis Terrarum.

17 Nota bene z pewnością przyczyniło się to, podobnie jak w Libii Muammara Kaddafiego, do upadku lub poważnego zachwiania reżimu, krytykowanego namiętnie przez islamskich radykałów, alergicznie reagujących na wszelkie przypadki westernizacji.

18 „Kontrolę nad [...] ustawami sprawuje od 1989 r. 12-osobowa Rada Strażników, będąca odpowiednikiem trybunału konstytucyjnego. W jej skład wchodzi 6 znawców prawa koranicznego (szarii) i 6 prawa cywilnego, orzekających o zgodności aktów prawnych z konstytucją i szarią" W. Ptah, Iran, [w:] Encyklopedia geograficzna świata, koord. serii W. Sawicki, t. 6, Kraków 1997, s. 335. Wynika z tego, że ustawy i inne dokumenty są legitymowane na dwa sposoby, co — przynajmniej teoretycznie — powinno utrudniać ,produkowanie jurydycznych bubli”.

${ }^{19}$ Koncepcja dwunastego imama szyickiego w szyizmie dwunastkowym, http://www.psz. pl/117-polityka/koncepcja-dwunastego-imama-szyickiego-w-szyizmie-dwunastkowym (dostęp: 11.02.2020). 
W innych muzułmańskich państwach teologowie nie odgrywają tak znaczącej roli jak w Iranie, ponieważ sunnicka wersja islamu pozbawiona jest zhierarchizowanego kleru, co nie oznacza wszakże, że przywódcy mogą lekceważyć religię. Nomenklaturowo najbliższe tradycyjnym wzorcom ustrojowym są: Sułtanat $\mathrm{Omanu}^{20}$, Sułtanat Brunei ${ }^{21}$ oraz położone nad Zatoką Perską (Arabską) emiraty. W przeciwieństwie do europejskich królestw w tych państwach ich nazwy wciąż jeszcze w dużej mierze odpowiadają zarówno konstytucyjnym rozwiązaniom, jak i praktyce ustrojowej. Silny jedynowładczy rys odnajdziemy też w pozostałych islamskich państwowościach, w których pamięta się przecież o tym, że najdoskonalszą w przekonaniu wiernych wspólnotą polityczną był zorganizowany przez Mahometa kalifat, charakteryzujący się tym, że w owej religijno-politycznej gminie rozstrzygającą rolę odgrywał Prorok. Ustanowił on słuszny wzorzec państwowości i obowiązkiem każdego islamisty jest ze wszystkich sił dążyć, aby próbować go odtworzyć, a zatem monokratyczny ideał jest głęboko zakorzeniony w muzułmańskim idearium.

Konfesyjno-cywilizacyjny dystans między krajami zrzeszonymi w Organizacji Państw Islamskich a euroamerykańską „,bogatą Północą” sprawia, że niezależnie od ubierania przez sułtanaty, emiraty, królestwa czy republiki konstytucyjnych szat ich polityczne reżimy charakteryzują się sporą swoistością w zestawieniu z uogólnionym północnoatlantyckim wzorcem. Wynika to przede wszystkim z tego, że na obszarach byłego Trzeciego Świata trudno zauważyć podobne do nordyckich czy romańskich społeczeństwo obywatelskie. Często, szczególnie w Afryce, jak też w Azji i Oceanii, a gdzieniegdzie (w krajach z dużymi indiańskimi populacjami) także w Latynoameryce, wciąż jeszcze nie mamy do czynienia z ukształtowanymi narodami, które można by wychowywać w oświeceniowo-ludowładczo-nomokratycznym duchu. Na sporych połaciach Ziemi wciąż jeszcze, pomimo oficjalnego wykreślenia międzypaństwowych granic, ciągle solidnie trzyma się niejednokrotnie animalistyczny trybalizm. Ludziom wychowanym w przenikniętej przez plemienność rzeczywistości trudno pojąć stworzone wskutek przekształcenia eklezjalnych pierwowzorów pojęcia, jakimi przepełniony jest wywodzący się z chrześcijaństwa konstytucyjno-ludowładczy paradygmat ${ }^{22}$. Trochę inna, ale zasadniczo podobna gnoseologiczna zagwozdka występuje w wypadku muzułmanów, buddystów, konfucjanistów etc., operujących swoistymi myślowymi kategoriami. Łatwiej jest im niż zagnieżdżonym w plemiennym światku bliźnim pojąć

20 Zob. Sultanat Omanu. Prawo Podstawowe z dnia 6 listopada 1996 r., https://biblioteka. sejm.gov.pl/konstytucje-swiata-oman/ (dostęp: 15.02.2020).

${ }^{21}$ „W państwie tym sułtan „ma pełnię władzy wykonawczej. W jej sprawowaniu pomagają mu cztery organy konstytucyjne o kompetencjach doradczych: Rada Religijna, Rada Tajna, Rada Gabinetu Ministrów i Rada Sukcesyjna" — M. Jędrusik, Brunei, [w:] Encyklopedia geograficzna..., s. 234. Wymienienie Rady Religijnej na pierwszym miejscu wymownie świadczy o znaczeniu, jakie przypisuje się konfesji w noszącym piękną nazwę Państwa Brunei Kraju Pokoju sułtanacie.

22 Zob. C. Schmitt, Teologia polityczna i inne pisma, Warszawa 2012, passim. 
potrzebę (albo nieszczęście według anarchistów) doskonalącej się państwowości, ale zagadnienie niezależnych sądów lub parlamentaryzmu pozostanie raczej dla nich obcym abstraktem, nienależącym do sfery koniecznych bytów.

Nie jest zatem przypadkiem, że najbardziej popularnym ustrojem politycznym w onegdajszym Trzecim Świecie jest najbardziej symplicystyczna wśród istniejących modeli monokracja, występująca współcześnie zazwyczaj jako łatwo przyswajalny przez ogół prezydencjalizm. Przyozdabiana jest ona w modny dodatek w postaci ustawy zasadniczej, w której można odnaleźć wykaz oficjalnych instytucji politycznych, lecz przecież wiadomo nie od dzisiaj, że papier jest cierpliwy, z czego wynika, że często gęsto nie należy przywiązywać zbyt wielkiej wagi do konstytucyjnych norm, albowiem pays legal oraz pays réel lubią różnić się od siebie. Na aktualnym etapie rozwoju czy też trwania wiele wskazuje na to, że konstytucjonalizm oraz demoliberalizm przestały się rozwijać, a zatem trudno się spodziewać, żeby aktualny stan rzeczy uległ zmianie.

\title{
REFLECTIONS CONCERNING CREATION AND IDENTITY OF CONSTITUTIONAL POLITICAL REGIMES IN THE FORMER THIRD WORLD
}

\author{
Summary
}

Formalised constitutionalism actually is present in almost the whole World, as is also the case in the states of the former Third World. They march in the way indicated by the creators of the Anglo-Saxon Constitution in Philadelphia — initially the statehoods of Latin America and Liberia as "African America". Later constitutionalism conquered Asia, with China and India, as well as Oceania. The specific sphere of the "poor South" constitutes Islamic countries, where persistently the main law is based on the Koran. In most cases we observe a formally constitutionalised monocracy, which is the natural form of political community. Over the next years it is likely that this situation will be similar, because constitutionalism and liberal democracy are in the phase of decadence.

Keywords: constitution, constitutionalism, political regime, Third World

\section{BIBLIOGRAFIA}

Eakin M.C., Historia Ameryki Łacińskiej. Zderzenie kultur, Kraków 2009.

Fenby J., Chiny. Narodziny i upadek wielkiej potegi, Kraków 2009.

Goduń T., Cygnarowski M., Dudek S., Iwaniszczuk P., Pietrzak B., Lewicki M., Turcja (Republika Turecka), [w:] T. Goduń, M. Cygnarowski, S. Dudek, P. Iwaniszczuk, Leksykon systemów politycznych, Warszawa 1999.

Jędrusik M., Brunei, [w:] Encyklopedia geograficzna świata, koord. serii W. Sawicki, t. 6, Kraków 1997.

Koncepcja dwunastego imama szyickiego w szyizmie dwunastkowym, http://www.psz.pl/117-polityka/ koncepcja-dwunastego-imama-szyickiego-w-szyizmie-dwunastkowym (dostęp: 11.02.2020). 
Królestwo Lesotho. Konstytucja z dnia 2 kwietnia 1993 r., http://biblioteka.sejm.gov.pl/konstytucje-swiata-lesotho/ (dostęp: 15.02.2020).

Królestwo Suazi. Konstytucja z dnia 26 lipca 2005 r., http://biblioteka.sejm.gov.pl/konstytucje-swiata-suazi/ (dostęp: 15.02.2020).

Kuba proklamowata nowa konstytucję. Castro: przygotujcie się na braki w zaopatrzeniu, https:// tvn24.pl/swiat/kuba-nowa-konstytucja-proklamowana-przez-zgromadzenie-narodowe-ra926432-2310532 (dostęp: 15.02.2020).

Kula M., Historia Brazylii, Wrocław-Warszawa-Kraków-Gdańsk-Łódź 1987.

Liberja, [w:] S. Orgelbrand, Encyklopedja powszechna z ilustracjami i mapami, t. 9, Warszawa 1901.

Libierija: pieczial'naja istorija ,,Swobodnoj strany”, https://topwar.ru/54963-liberiya-pechalnaya-istoriya-svobodnoy-strany.html (dostęp: 8.02.2020).

Łepkowski T., Haiti: początki państwa i narodu, Warszawa 1964.

Ptah W., Iran, [w:] Encyklopedia geograficzna świata, koord. serii W. Sawicki, t. 6, Kraków 1997.

Reychman J., Historia Turcji, Wrocław-Warszawa-Kraków-Gdańsk 1973.

Rowiński J., Jakubiec W., System konstytucyjny Chińskiej Republiki Ludowej, Warszawa 2006.

Schmitt C., Teologia polityczna i inne pisma, Warszawa 2012.

Smirnow E.G., Obszczije swiedienija, nasielienije, chozjastwo, [w:] Liberija, „Bol'szaja Rossijskaja Encikłopiedija", https://bigenc.ru/geography/text/2649384 (dostęp: 8.02.2020).

Sultanat Omanu. Prawo Podstawowe z dnia 6 listopada 1996 r. https://biblioteka.sejm.gov.pl/konstytucje-swiata-oman/ (dostęp: 15.02.2020).

Wiktor Z., Chiny na drodze socjalistycznej modernizacji, Toruń 2008. 